\title{
The Impact of the digitalization and the policy changes on the Savings Instruments (Saving Certificates) in Bangladesh: a response from the investors.
}

\author{
Ashish Basak ${ }^{1}$ \\ ${ }^{1}$ Lecturer, Department of Business Administration, Shanto-Mariam University of Creative Technology, \\ Dhaka, Bangladesh.
}

\begin{abstract}
Investment in the National Savings Certificate (NSC) has been the most popular savings instrument among the people of Bangladesh that provides guaranteed returns with tax savings. The government of Bangladesh mainly issues the NSCs to collect money from small and scattered savings of general people. It brings marginal and special populations into the Government's social safety net programs for ensuring an equitable and poverty-free society. Recently the authority has introduced automation and regulatory deterrents such as making mandatory the submission of e-TIN, national identity cards, bank accounts, cheque transactions, and increased deduction at source. My research has attempted to identify the impact of the policy changes on the investors' minds and how they react. This study suggests that recent policy changes and the requirement for the mandatory documents to purchase NSCs have no impact on the investment decision as people still consider this is the most attractive and secure means of investment.
\end{abstract}

Keywords: Saving Instruments, NSCs, TDS, e-TIN

\section{Introduction}

The National Savings Certificate (NSC) is a popular and safe small-savings instrument that combines tax savings with guaranteed returns. Sanchayapatra, also known as National Savings Certificate in Bangladesh, is regarded as a risk-free investment in Bangladesh. Over the years, it has become a part of the savings mobilization scheme of the Government of the People's Republic of Bangladesh (Ministry of Finance, 2019). Sanchayapatra (National Savings Certificate) encompasses different types of savings schemes operated by the National Savings Department, Bangladesh. This project is monitored and supervised by the Internal Resources Division of the Ministry of Finance of the Government of Bangladesh. Savings certificates are considered a form of loan for the government because it has to pay monthly interest to savings certificate holders. (National Budget Speech, 2021).

The NSCs are issued mainly to collect money from small and scattered savings of general people. It has been started to bring marginal and special populations into the Government's social safety net programs for ensuring equitable and poverty-free society (Ministry of Finance, 2019). It is presumed that selling NSCs to those populations may help to develop their savings habit. Besides, deficit financing through NSCs controls the fear of inflation as it does not require printing money as well as reducing dependency on foreign loans (World Bank, 2021). The main aim of these savings certificates is to protect women, retired government employees, senior citizens, non-resident Bangladeshis, and disadvantaged marginalized citizens. In the absence of a well-functioning pension and social security system, these savings certificates have been working as a social safety net for many people (National Budget Speech, 2021).

In recent years, the government has introduced several mandatory requirements such as e-TIN certificate, Bank account \& NI Number for the investors to be able to invest in the national saving certificates. At the 
same time, the return on investment rates have been reduced and the Tax Deduction at Source (TDS) has made been increased. The study aims to investigate the impact of the recent changes on the investors' mind and how they react in response to the police change.

\section{Literature Review}

Savings are indispensable for economic growth. Countries with high level of savings tend to have lower inflation, high level of investment and sustainable economic growth. In all the countries of the world, household savings contribute substantially to national savings. Households' savings are an important source of capital to fund investment and growth in the economy (Alade, 2006). Moreover, some recent studies tried to identify determinants of savings on the perspective of regional, national and cross country using mostly secondary data/information. Aric, K. H.,(2015) analysed secondary panel data from the World Bank for sixteen APEC member countries during 2000-2013 by Pooled OLS method and found that income, age dependency ratio, young population, rural population and urban population influence savings positively while financial depth effects on savings negatively. They also found that inflation and old population have no role in savings in APEC countries. Bhandari et al. (2007) observed that Government expenditures and past savings have a significant negative role in determining private savings in five South Asian countries namely Bangladesh, India, Nepal, Pakistan and Sri Lanka. However, financial development and raise in income per capita promote people to save more. The rate of dependency, localization level and real interest rates appear to have less impact on private savings in these countries.

Imran et al. (2017) showed that inflation, tax and gross domestic product have statistically significant positive impacts on the gross domestic savings while per capita income, interest, money supply growth and age dependency ratio have a non-significant effect on gross domestic savings in six South Asian countries. Similarly, Das and Ray (2012) analysed panel data for1990-2007 period of developing six Asian (China, India, Indonesia, Malaysia, the Philippines and Thailand) economies that have high savings rates and observed that high growth, low age dependency, an increasing degree of financial deepening, presence of liquidity constraint, remittances, terms of trade shock and human capital formation are leading determinants of the savings for these countries.

Another study conducted by the Research Department of Bangladesh Bank on NSCs considering total sample 1336 based on field survey in 2011 in seven divisional cities of Bangladesh. The study intended to find out the basic socio-economic characteristics of investors in national savings certificates that influenced the investment decisions in NSCs, problems in encashment and other services related, and way out what features can make NSCs attractive to the investors as it serves as a very important window of financing for Government budget deficit. The report identified that most of the NSCs buyers were male (52.5 percent), investors mostly resided in urban areas $(83.15 \%)$ and only a marginal number of investors were from rural areas $(16.5 \%)$. Most of the investors $(77.4 \%)$ felt investment in NSCs attractive, mainly due to safety and security. While a large number of NSCs buyers stated that they found investment in NSCs unattractive due to its lower return as compared to FDR rate in commercial banks. Moreover, the study recommended to rationalize and adjust the interest rate of NSCs in line with commercial bank's FDR rate; create special savings schemes for the person retired from private organizations and for widows, ensure availability of the scripts and forms in all state-owned and private commercial banks, and post offices, upgrade service standard, introduce online sales, profit withdrawal and encashment facilities for NSCs.

\section{Types of National Saving Certificates}

The government securities market of Bangladesh is consisted of tradable and non-tradable securities. Nontradable securities include National Savings Certificates i.e. Sanchayapatras and Sanchaya bonds which are only for retail investors. Different types of savings schemes are being conducted by the National Savings Directorate of Bangladesh under the supervision of the Internal Resources Division of the Ministry of 
Finance of the Government of Bangladesh. There are various types of National Savings Certificates; of which the popular certificates are as follows:

Family Saving Certificates: This saving scheme, also known as the Paribar Sanchayapatra. It is a 5-year long saving scheme. This scheme is specially designed for women. Any woman who is more than 18 years old can invest in Paribar Sanchaypatra. The minimum investment for this scheme is Tk. 10000/ and the maximum limit is Tk. 45,00,000/. This schema typically provides a return of around $11.52 \%$ if encashed after maturity (Department of National Saving, 2021). Pensioner Saving Certificates: This scheme is also known as Pensioner Sanchayapatra. Any retired government and semi-government employees who have a minimum employment period of 20 years can invest in this scheme. Generally, the returns are around $11.56 \%$ for withdrawal after 5 years. The returns vary for premature withdrawal, and it depends on the number of years of investment in the scheme (Bangladesh Bank, 2021). Quarterly Profit based Savings: This scheme is known as Tin Mash ontor munafa vittik Sanchayapatra. This scheme requires a minimum investment of Tk. 1,00,000/- and has a maturity period of 3 years. A single person can invest a maximum of Tk. 30,00,000/- and for joint owner maximum limit is Tk. 60,00,000/. Generally, the returns of this scheme are around $11.04 \%$ for the complete tenure of 3 years. The returns vary for premature withdrawal, and it depends on the number of years of investment in the scheme. (Bangladesh Bank, 2021). Bangladesh Saving Certificates: In this scheme, the maximum investment limit is Tk. 30,00,000/- for individual investors and Tk. 60,00,000/- for joint investors. This is a five years scheme and provides a return of around $11.28 \%$ at maturity. The returns vary if the investor withdraws before maturity and it depends on the number of years of investment in the scheme. (Department of National saving, 2021).

\section{Return on investment}

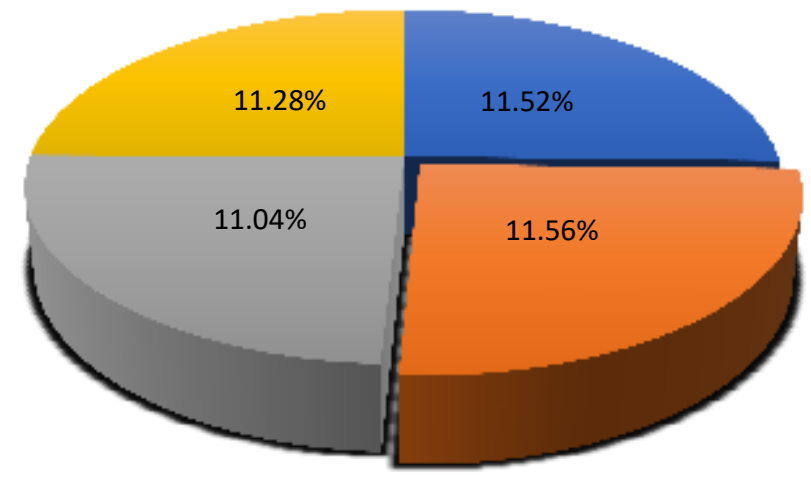

- Family Saving Certificates $\quad$ Pensioner Saving Certificates
Quarterly Profit based Savings $\square$ Bangladesh Saving Certificates

Source: Department of National savings

\section{Ceilings for investing in Savings Instruments}

Sales of the savings certificates picked up in recent times, and in response, the government has reduced the ceilings. The government lowered the maximum investment ceilings of purchasing three types of savings certificates. (Akter. D 2020). The certificates are - Five-Year Bangladesh Sanchaypatra, Three-Month Profit-Based Sanchaypatra, and Paribar Sanchaypatra (family savings certificate). Small investors can now purchase these savings certificates up to Tk. 5.0 million in total in a single name, and Tk. 10 million in joint names, whereas the previous ceiling was Tk. 10.50 million and Tk. 12 million respectively. An individual can now buy the three types of savings certificates worth up to Tk. 1.05 crore in total. 
Both policymakers and economists have suggested discouraging investment in savings certificates to ease the burden of costly borrowing tools and to help the banks lower their interest rates. Earlier, an investor could buy Bangladesh Sanchaypatra worth up to Tk. 3.0 million, Three-Month Profit-Based Sanchaypatra up to Tk. 3.0 million, and Paribar Sanchaypatra worth up to Tk. 4.5 million in a single name. The investors were also allowed to purchase Bangladesh Sanchaypatra worth up to Tk. 6.0 million, and Three-Month Profit-Based Sanchaypatra up to Tk. 6.0 million in joint names (NEWAGE, 2021).

\section{Increased Tax Deduction at Source (TDS) for the NSC}

The tax on savings certificates has been increased to 10 percent from 5 percent in the current fiscal year to discourage the purchase and keep the government's borrowing from this high-interest-bearing instrument within target. In case of investments not exceeding Tk.5 lakh, source tax would be deducted at the rate of 5 percent (NBR, 2021). According to the Bangladesh Bank, profit along with principal would be treated as fresh investment in case of auto reinvestments in five-year national saving certificates (NSCs), and the applicable source tax will be determined based on the invested amount. For auto reinvestment of five-year national saving certificates, source tax at the rate of 10 percent would be deducted if investments exceed Tk.5 lakh.

\section{Making the e-TIN mandatory for NSC}

Electronic Taxpayer Identification Number (e-TIN) has been made mandatory for purchasing national savings certificates and opening a postal savings account exceeding Tk.200,000 (NBR, 2021). Since many of the savers were not familiar with the online process and had no electronic Tax Identification Number (eTIN), they could not purchase such tools (Arafat Ara ,2020). One has to submit multiple documents, including e-TIN to buy the borrowing instruments. Besides, national identity cards, bank accounts, mobile numbers, and cheque transactions are also mandatory while investing in risk-free instruments. The government is considering the measure as a means to prevent money laundering. (Mowla,G, 2019).

\section{Digitalization of the NSC}

The government launched savings certificates online database named 'National Saving Certificates Online Management System' to check violations of the limit of savings certificates and identify the investors (Hossain,S, 2019). Real-time information is available now on the sale, profit and encashment of national saving schemes from the 'National Saving Scheme Online Management System'. The automation, which allows people to open accounts and deposit and withdraw funds very quickly, gets rid of the misuse of the benefit under the existing system. The database will keep in check the investment within the limit as well as ensure the transparency of the funds.

The government has already automated four types of popular savings schemes (Department of National Saving, 2021) : five-year tenure Bangladesh savings scheme, three-month interest-based savings scheme, family savings scheme and pensioner savings scheme. They are being sold at 1,659 branches under banks, post offices and the Department of National Savings (DNS).

\section{Methodology \\ Nature of the Research}

This is descriptive research in nature where a survey questionnaire was used to collect quantitative data to realize the challenges and opportunities of the NSC policy changes. To be precise, this study involved a cross-sectional design in which there were multiple respondents, and information from each respondent was collected only once. The study uses both primary and secondary data. A field survey was conducted during January- March 2021 through face- to- face interview with investors of the NSCs to gather the primary data. 
Total 513 investors of NSCs had been interviewed on a random basis from Tangail, Gazipur \& Dhaka districts in Bangladesh.

\section{Research Questions}

The researcher asked several research questions that were guided by the specific objectives of the study. The collected data have been analysed based on the true response of the respondents. The researcher has always been unbiased and objective in analysing the collected data to conclude. Theoretical framework as well as the analytical model has been adopted in this study. Research questions were as follows:

- To investigate the impact of the increased Tax Deduction at Source (TDS) on the NSC investment.

- To explore the difference in waiting time before and after the introduction of the online system.

- To apprehend the investors' feelings in regards to making the e-TIN certificate a mandatory document.

- To recognize the investors' reaction to the introduction of the online recording system.

- To explore the impact of the tax credit opportunity on investing decisions.

\section{Data Analysis Techniques}

For data analysis, the researcher relied upon graphical approach and some descriptive approach using SPSS version 25.0 and EXCEL outcome. Through a graphical approach, I have presented some parameters that change the investor's behaviours and views in introducing the automation and policy changes.

\section{Results of the data Analysis}

The researcher has always been unbiased and objective in analysing the collected data to conclude. The information was collected through personal interviews of the investors and the offices of the Bangladesh National Savings Bauru were visited to collect the data. This pie chart shows the percentage of males and females that responded to the questionnaire. In a sample of size 513 people, $55 \%$ were males and $45 \%$ were females.

\section{GENDER ORIENTATION}
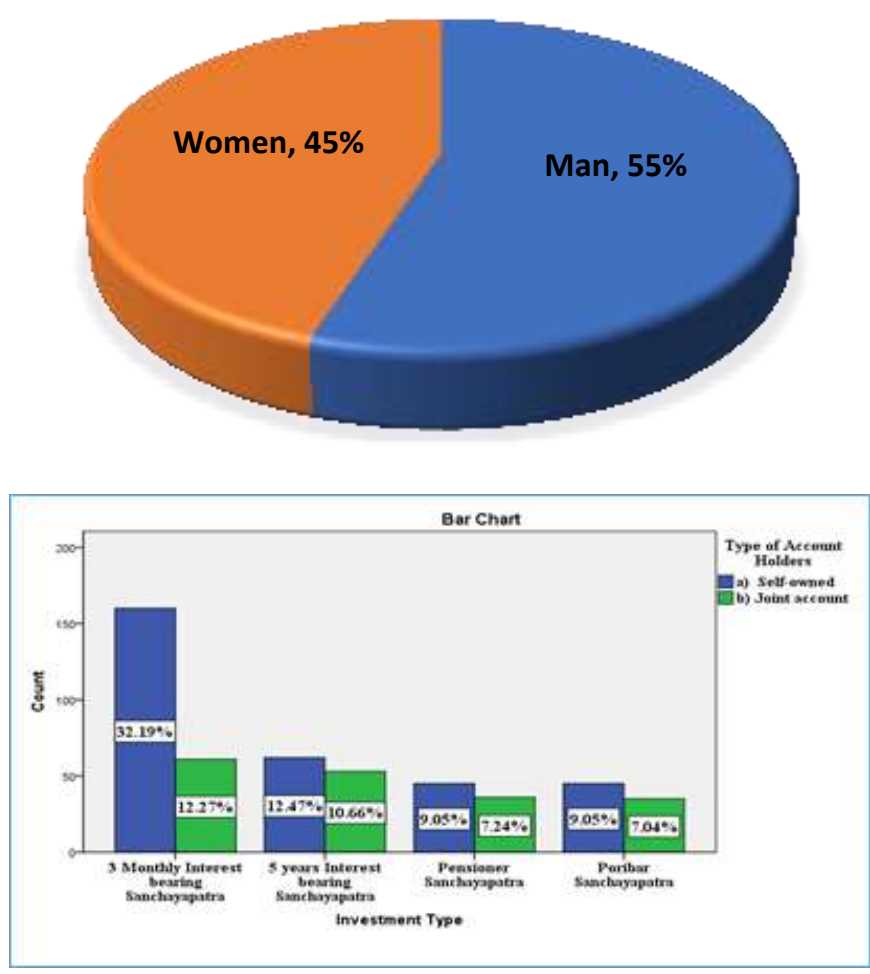
Through the analysis, the types of investments and the account holders have been identified. Bases on the respondents' status it is obvious that people are more likely interested in ' 3 Monthly Interest Bearing Sanchayapatra' investment with $44.64 \%$ divided into $32.19 \%$ as self-owned accounts holders and $12.27 \%$ as joint accounts holders. While for the other three types of investments, the percentage is almost the same, it varies between $16 \%$ and $22 \%$ for both account holders. It has been observed that the majority of the ' 3 Monthly Interest Bearing Sanchayapatra' investors maintain self-owned accounts.

My first objective is to establish the relationship between the increased source of deduction (5\% to 10\%) and the investors' decision to withdraw. To find out the result, I have run a Chi-Square test, taking into consideration the null and alternative hypothesis as follows:

Null Hypothesis: The investor's decision did not get affected by the increased source of deduction. (Independent variable)

Alternative Hypothesis: The investor's decision got affected by the increased source of deduction. (Dependent variable)

\section{Cross tabulation}

\begin{tabular}{|c|c|c|c|}
\hline & \multicolumn{2}{|c|}{$\begin{array}{c}\text { Have you withdrawn any } \\
\text { investment from NSC since July? }\end{array}$} & \multirow[b]{2}{*}{ Total } \\
\hline & a. Yes & b. No & \\
\hline Do you know that the source a) Yes & 158 & 276 & 434 \\
\hline $\begin{array}{ll}\text { of deduction has been } & \text { b) No } \\
\text { increased } 5 \% \text { to } 10 \% ? & \end{array}$ & 18 & 53 & 71 \\
\hline Total & 176 & 329 & 505 \\
\hline
\end{tabular}

\section{Chi-Square Tests}

\begin{tabular}{|c|c|c|c|c|c|}
\hline & Value & df & $\begin{array}{c}\text { Asymptotic } \\
\text { Significance (2- } \\
\text { sided) }\end{array}$ & $\begin{array}{c}\text { Exact Sig. (2- } \\
\text { sided) }\end{array}$ & $\begin{array}{c}\text { Exact Sig. (1- } \\
\text { sided) }\end{array}$ \\
\hline Pearson Chi-Square & $3.283^{a}$ & 1 & .070 & & \\
\hline Continuity Correction ${ }^{\mathrm{b}}$ & 2.815 & 1 & .093 & & \\
\hline Likelihood Ratio & 3.430 & 1 & .064 & & \\
\hline Fisher's Exact Test & & & & .081 & .045 \\
\hline Linear-by-Linear Association & 3.277 & 1 & .070 & & \\
\hline $\mathrm{N}$ of Valid Cases & 505 & & & & \\
\hline
\end{tabular}

a. 0 cells $(.0 \%)$ have expected count less than 5. The minimum expected count is 24.74 .

b. Computed only for a $2 \times 2$ table

At 5\% level of significance follows chi-square distribution and a degree of freedom of 1

$\mathrm{x}^{2}{ }_{0.05}=3.84>\mathrm{x}_{\text {cal }}^{2}=3.283$

$\mathrm{P}$-value $=0.07>0.05$

So I fail to reject my null hypothesis, at a 5\% level of significance, I can say that the investor's decision doesn't get affected by the increased source of deduction. 


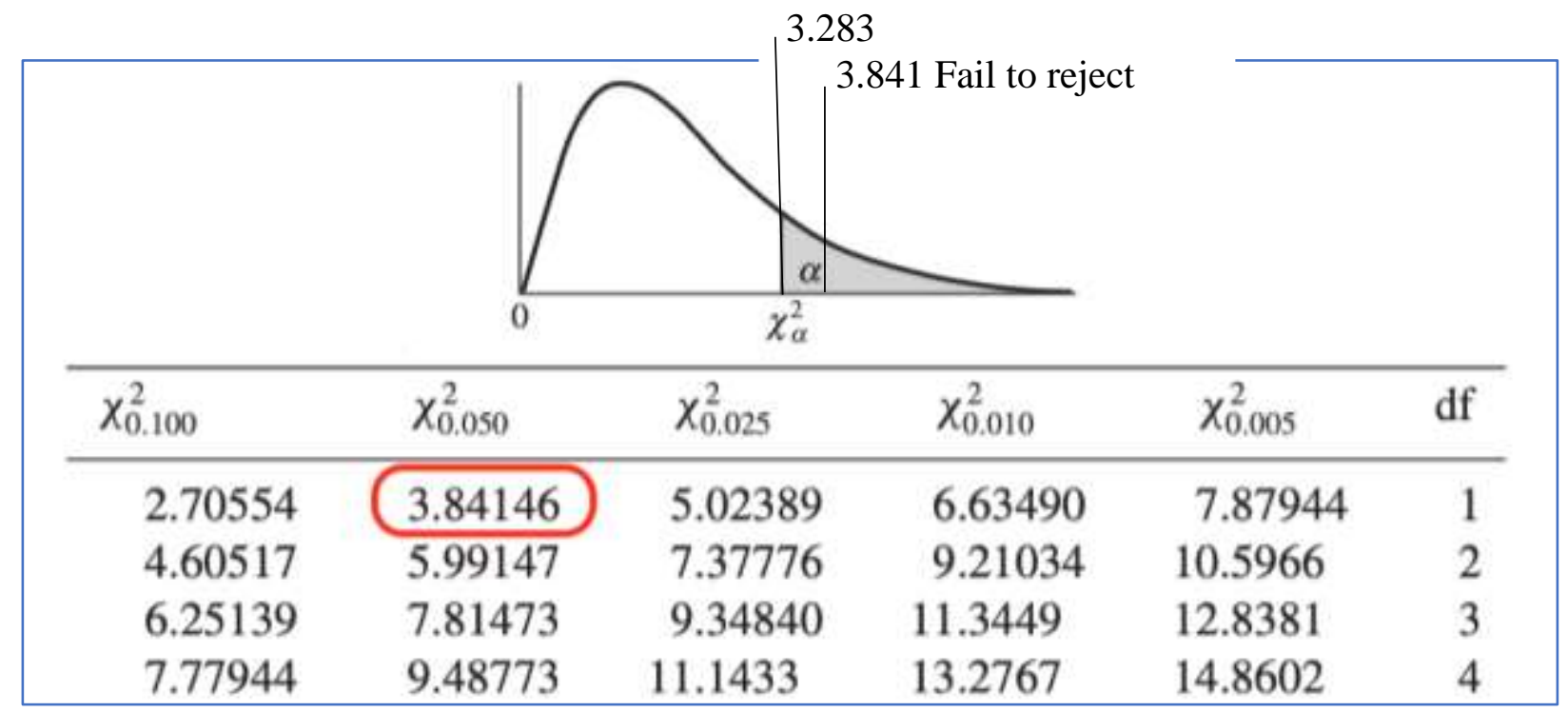

This graph represents the rejection part of the null hypothesis, which is the grey part, while in the white part I fail to reject H0. As it is seen, the observed value (3.283) is in the white part, where I cannot reject my null hypothesis, taking into consideration that the critical value is taken from the chi-square table shown above with 1 degree of freedom and risk of $5 \%$.

My second objective is to see whether there is any difference in waiting time before and after the introduction of the online system. To run the study, I asked the people how long on average they had to wait before and how long they have to wait now to get their papers works done. Before running a paired t-test to analyse

my result, I need to prove the assumption of normality of the difference in waiting time between before and after the introduction of online system
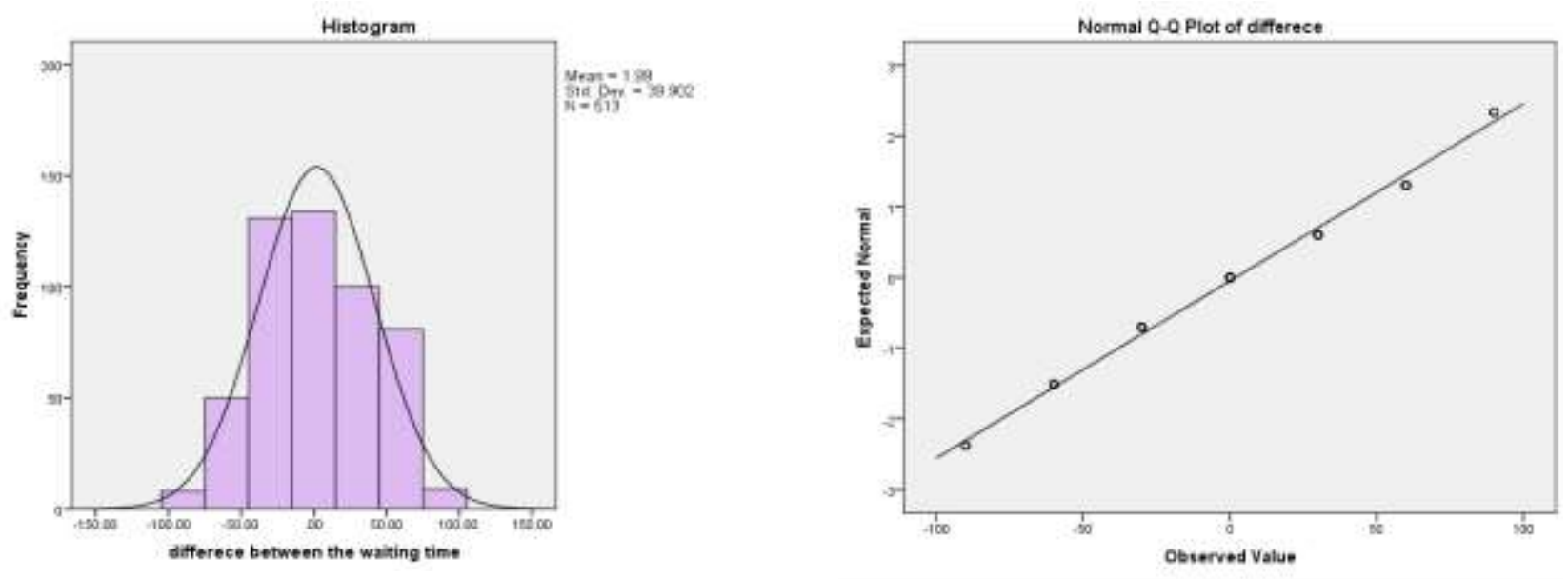

From

the curve shown on the histogram above and the Q-Q plot, I can say that the difference is normally distributed.

It is possible to assume the normality by the values of skewness and kurtosis. Where $\mid$ skewness $\mid=0.53<0.8$ and $\mid$ kurtosis $\mid=0.704<2$ shown in the following table.

Descriptive

\begin{tabular}{|c|c|c|c|c|}
\hline & & & Statistic & Std. Error \\
\hline \multirow[t]{2}{*}{ difference } & Mean & & 1.9883 & 1.76170 \\
\hline & $95 \%$ Confidence Interval for & Lower Bound & -1.4727 & \\
\hline
\end{tabular}




\begin{tabular}{|l|r|r|}
\hline Mean & 5.4493 & \\
\hline 5\% Trimmed Mean & 2.1442 & \\
\hline Median & .0000 & \\
\hline Variance & 1592.133 & \\
\hline Std. Deviation & 39.90154 & \\
\hline Minimum & -90.00 & \\
\hline Maximum & 90.00 & \\
\hline Range & 180.00 & \\
\hline Interquartile Range & 60.00 & \\
\hline Skewness & .053 & .108 \\
\hline Kurtosis & -.704 & .215 \\
\hline
\end{tabular}

A paired t-test has been run to see whether there exists a significant difference between the waiting time before and after the introduction of computers. To investigate the result, I have run a Paired Samples Statistics test, taking into consideration the null and alternative hypothesis as follows:

Null Hypothesis: the average waiting time before and after the introduction of computer does not differ significantly $(\mathrm{m} 1=\mathrm{m} 2)$

Alternative Hypothesis: there is a significant difference between the average waiting times $(\mathrm{m} 1 \neq \mathrm{m} 2)$

Paired Samples Statistics

\begin{tabular}{|ll|l|l|l|c|}
\hline & Mean & $\mathrm{N}$ & Std. Deviation & Std. Error Mean \\
\hline Pair 1 & $\begin{array}{l}\text { How long on average do you } \\
\text { have to wait now to get your job } \\
\text { done? }\end{array}$ & 77.78 & 513 & 31.146 & 1.375 \\
$\begin{array}{l}\text { how long did you have to wait to } \\
\text { get your job done before the } \\
\text { introduction of the computer } \\
\text { system? }\end{array}$ & 79.77 & 513 & 34.095 & 1.505 \\
\hline
\end{tabular}

Paired Samples Correlations

\begin{tabular}{|ll|l|l|l|}
\hline & & $\mathrm{N}$ & Correlation & Sig. \\
\hline Pair 1 & $\begin{array}{l}\text { How long on average do you have to wait now } \\
\text { to get your job done? } \\
\text { how long did you have to wait to get your job } \\
\text { done before the introduction of the computer } \\
\text { system? }\end{array}$ & 513 & .254 & .000 \\
\hline
\end{tabular}

Correlation $\mathrm{R}=0.254$ means that there exists a weak relationship between the waiting time now and then. At a 5\% level of significance and from the paired t-test we got:

$\mathrm{P}$-value $=0.260<0.05$.

So we fail to reject the null hypothesis, consequently, there is no significant difference between the waiting time before and after the introduction of online system. Since our Paired Samples Statistics box revealed that the Mean waiting times before the computer (79.77) was almost the same as the Mean for waiting time after 
the computer (77.78), we can conclude that the introduction of the online system has not make a huge difference to reduce the waiting time.

Next, I have sought to realize the investors' reaction to the introduction of the computerized online recording system.

\begin{tabular}{|c|c|c|c|c|c|c|c|c|c|}
\hline \multicolumn{10}{|c|}{ Paired Samples Test } \\
\hline & & \multicolumn{5}{|c|}{ Paired Differences } & \multirow[b]{3}{*}{$\mathrm{t}$} & \multirow[b]{3}{*}{$\mathrm{df}$} & \multirow{3}{*}{$\begin{array}{l}\text { Sig. (2- } \\
\text { tailed) }\end{array}$} \\
\hline & & \multirow[b]{2}{*}{ Mean } & \multirow{2}{*}{$\begin{array}{l}\text { Std. } \\
\text { Deviation }\end{array}$} & \multirow{2}{*}{$\begin{array}{l}\text { Std. Error } \\
\text { Mean }\end{array}$} & \multicolumn{2}{|c|}{$\begin{array}{l}95 \% \text { Confidence } \\
\text { Interval of the } \\
\text { Difference } \\
\end{array}$} & & & \\
\hline & & & & & Lower & Upper & & & \\
\hline $\begin{array}{l}\text { Pair } \\
1\end{array}$ & $\begin{array}{l}\text { How long on average do } \\
\text { you have to wait now to get } \\
\text { your job done? } \\
\text { how long did you have to } \\
\text { wait to get your job done } \\
\text { before the introduction of } \\
\text { the computer system? }\end{array}$ & -1.988 & 39.902 & 1.762 & -5.449 & 1.473 & -1.129 & $\begin{array}{r}51 \\
2\end{array}$ & .260 \\
\hline
\end{tabular}

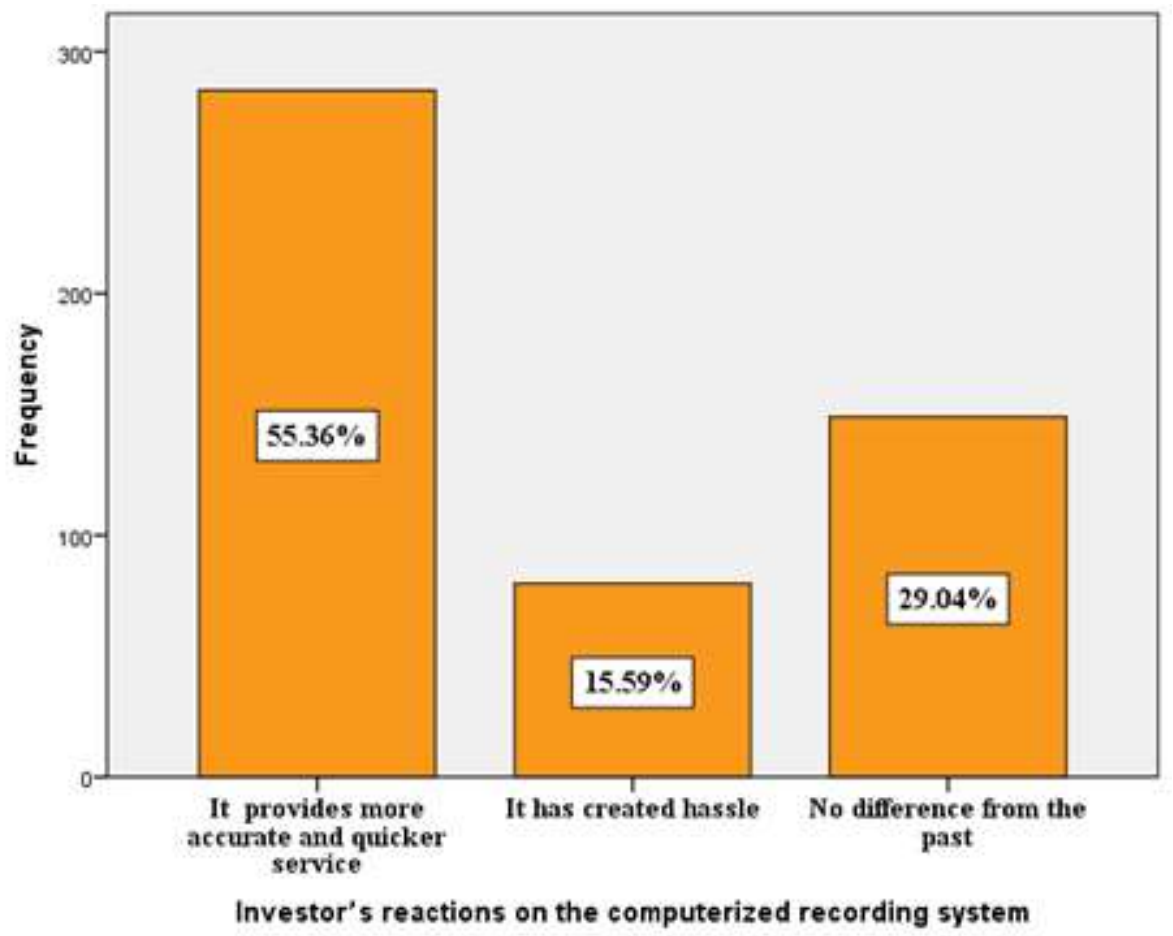

My analysis indicates that $55.36 \%$ people assumed computerized online recording system provides more accurate and quicker service, where $44.63 \%$ hasn't found it helpful by answering that it hasn't made any difference or has created hassles for them.

Furthermore, I have run a study to understand the investors' feelings in regards to making the e-TIN certificate a mandatory document. 


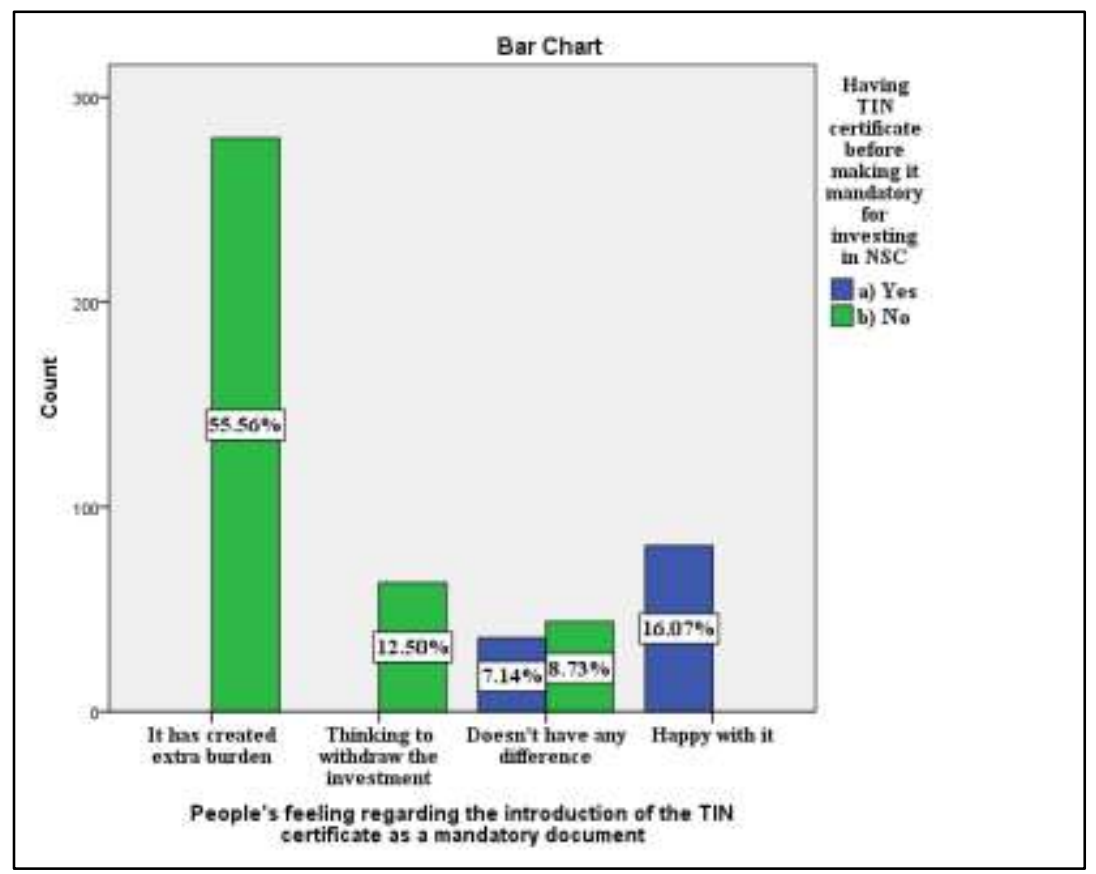

It is found that $55.56 \%$ of people do not like the introduction of the e-TIN certificate as a mandatory document since they did not have it before making it mandatory. They say that it has created an extra burden.

On the other hand, $16.07 \%$ of people who already have an e-TIN expressed their satisfaction with the introduction of the digitalized system. Finally, a minority of $8.73 \%$ of investors didn't know about it before but they have no problem with making it mandatory.

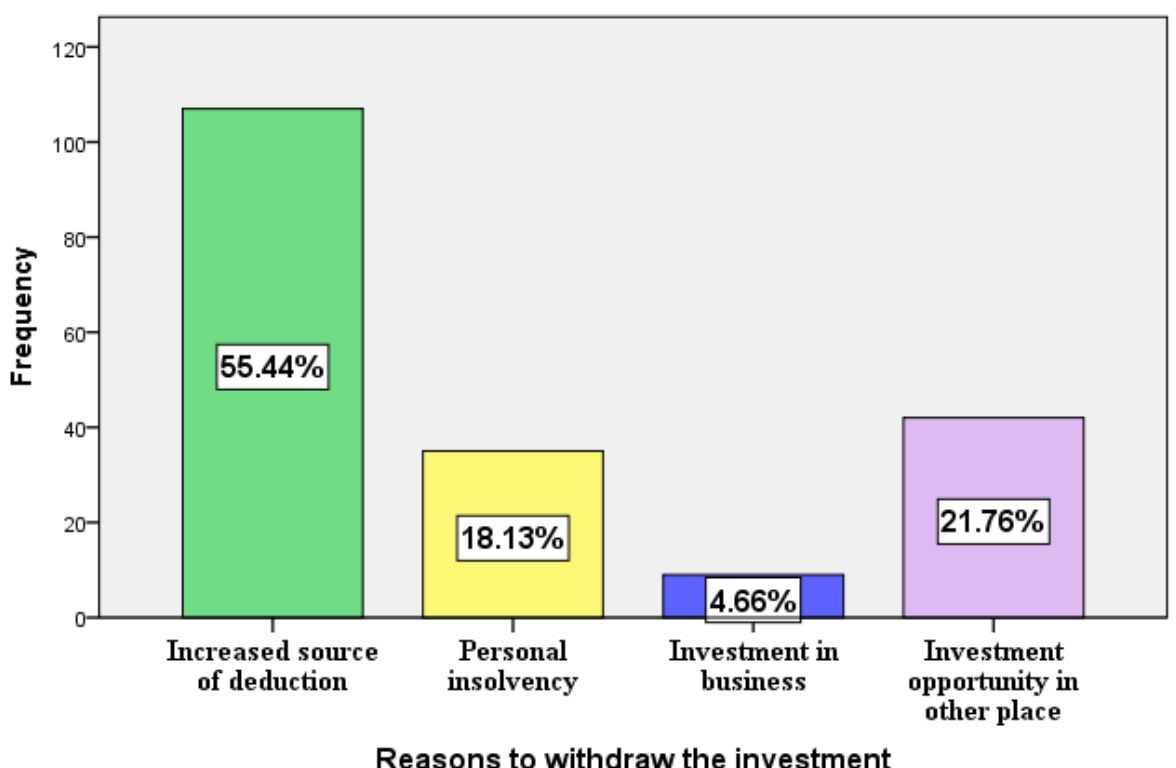

Later, I have tried to find out what had been the main causes people withdraw their investment from the NSCs, and I have found that $55.44 \%$ of people have withdrawn their investment due to an increased source of deduction. Some people withdraw their investment for having an opportunity to invest in another place that represents $21.76 \%$. A Small number of investors withdraw their savings for investing in their own business or personal reason.

Finally, an effort has been made to figure out the impact of the tax credit opportunity on investing decisions to national saving certificates. 


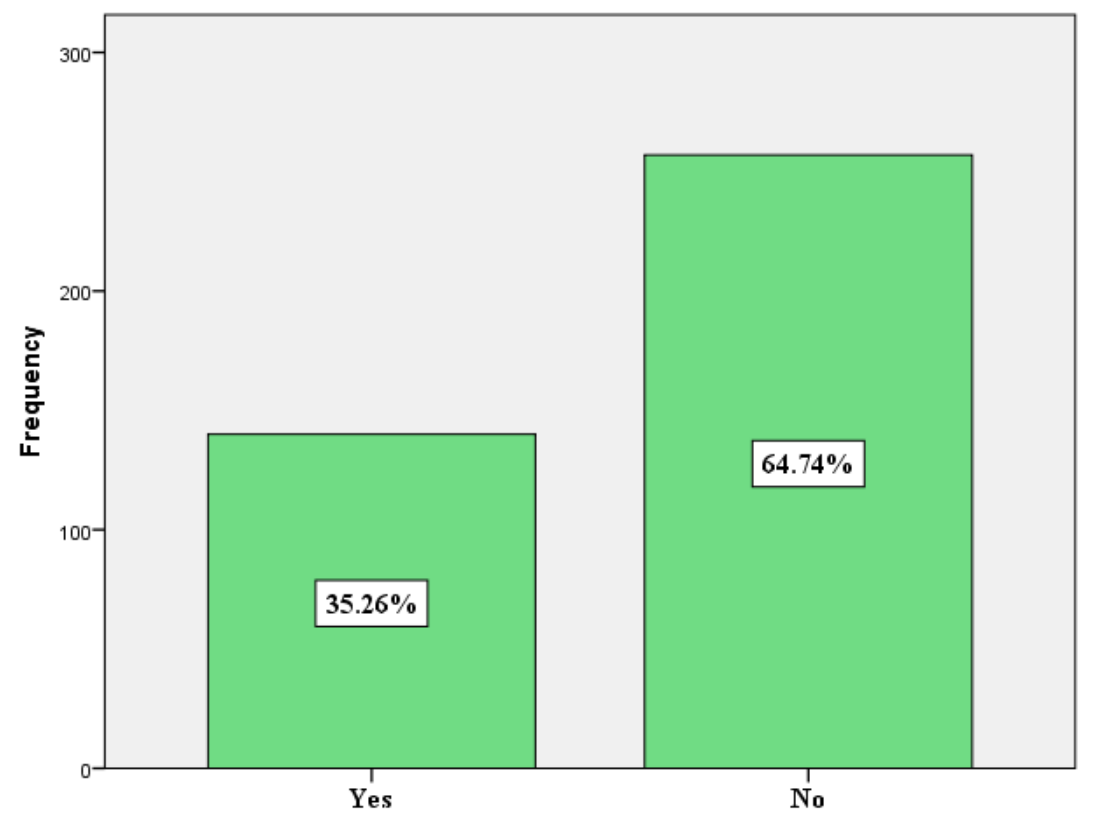

It was

Impact of the tax credit opportunity on investing decision to NSC

investigated to tax credit opportunity

understand if the

has any influence on the investor's decision to invest in the NSC, to end up with an obvious result, it doesn't have a huge influence. It affected the decision of $35.26 \%$ of investors, while $64.74 \%$ of people are not worried about it.

\section{Conclusion \& Recommendations}

The National savings certificates are a saving scheme for the small savers. Department of National Saving (DNS) explicitly states that bringing small savers under this scheme is one of its goals (Five Year Plan, 2015). Another important goal is to provide a social and financial safety net for certain groups of people such as women, retired government employees, senior citizens, non-resident Bangladeshis and physically challenged people. Although it was suspected that the sale of National Savings Directorate (NSD) certificates would come down significantly due to the automation and regulatory deterrents, this study suggests that recent policy changes and the requirement for the mandatory documents have less effect on the investment decision.

There are two main reasons behind people's preference for buy savings certificates. First, no inquiries are made regarding the origin of the buyers' funds. Second, interests on savings certificates are higher than those on other deposits. Investors are attracted to NSCs for being risk-free investments with high returns (Agrawal, M. 2009). In addition to that, the downing of bank deposit rates is pushing savers towards national savings certificates. The interest rate on NSC is much higher (on average 11\%) than the interest rate of bank FDs, which is now as low as 4 to $4.5 \%$ (Hasan, M 2018). Furthermore, the pandemic has made it difficult for people to invest elsewhere and the inefficient stock market remains unattached due high risk involved. Saving certificates is a means of ensuring social well-being and the overall development of the economy of the country. Government should encourage the small savers to invest in it by ensuring a favourable environment for them. The following initiatives could be taken to make the investors more confident in their investment:

- The middle-income group is the major investors of NSCs and they seek a stable source of income. Many families depend on the income from the investment, and reducing the rate of return would put pressure on the lifestyle of the families. Government should always keep the interest rates attractive and higher so that the investors feel secure.

- The Government should ensure that the target group especially, the small savers from the rural areas get easy access to purchase of NSCs via post office or rural bank branches which will effectively broaden the social safety net coverage and benefit the mass people. 
- There is no provision for recording the sources of income of NSCs buyers. Authority may ask the information about sources of income of the NSCs buyers with proper documentation so that black or illegal money can't enter into the NSCs market. This kind of documentation may help maintaining single-person exposure as well as ensure the safety net purpose of the Government.

- Those who come to buy NSC certificates have to face a long queue, in most cases this happen due to the shortage of staff. The authority should recruit more employees to offer better service to the investors. In addition to that, to reduce the sufferings of NSC buyers during waiting time NSC selling place can be modernized. For example, a digital display board may be introduced so that, sick or old people can patiently sit with their eyes on the display board.

- A national integrated online database keeping a record of the NSCs investors and their close relatives, i.e., a spouse may help prevent buying NSCs more than limits. Concerned authorities may ask National Identity Card (NID) of the investors and the person whose income is used. All the offices/institutions where NSCs are being sold may be interconnected through a network so that establishing a database of the investors could be possible.

- It is apparent that people invest in the National Savings certificates for the better return. If the government keeps reducing the rate of return and increasing the deduction at source, then investors will be demotivated, in response, they might withdraw their savings. As savings certificates are issued for the welfare of the society and the overall economic development of the country, it should provide some privilege to the investors.

\section{References}

1. Akter. D 2020 'Ceilings for investing in savings instruments lowered' viewed 10th December 2020.Financial Express, https://www.thefinancialexpress.com.bd/economy/bangladesh/ceilings-forinvesting-in-savings-instruments-lowered-16070

2. Agrawal, M. 2009. Interpreting the behaviour of investors on their expected returns. Journal Of Business Solutions, 2(1-2), pp.76-81.

3. Alade, S. O. (2006). "Enhancing Long-term Savings Culture in Nigeria Through National Saving Certificate", CBN Bullion, Vol. 30, No. 1, Jan-March.

4. Aric, K. H., 2015. Determinants of savings in the APEC countries. Theoretical and Applied Economics Volume XXII (2015), No. 2(603), summer, pp. 113-122.

5. Arafat Ara ,2020 'Sales of govt savings tools nosedive in July' -The Financial Express, Retrieve from: https://www.thefinancialexpress.com.bd/economy/bangladesh/sales-of-govt-savings-toolsnosedive-in-july-1599535919.

6. Bangladesh Bank 2021, Application forms for Purchasing Savings Instruments ,Bangladesh Bank, viewed 5th January2021https://www.bb.org.bd/investfacility/sanchayapatra.php

7. Bhandari, R.D.D., Pradhan, G. and Upadhyaya, K.P., 2007. Determinants of Private Saving in South Asia. South Asia Economic Journal. 8:2. pp. 205-217.

8. Das, S. and Ray, P., 2012. Does Developing Asia Save More? Evidence from a Panel of High Saving Nations in Asia. The IUP Journal of Applied Economics. pp. 29-55.

9. Department of National savings 2021, Existing saving schemes, Department of National savings, viewed 2nd January 2021, <http://www.nationalsavings.gov.bd/site/page/f172a332-610b-437>.

10. Five Year Plan ,2015 'Accelerating Growth, Empowering Citizens', General Economic Division, Planning Commission, Government of the People's Republic of Bangladesh

11. Hasan.M (2018) Savings certificate sales 'pushing up' govt. debt burden'. Retrieve from: https://www.dhakatribune.com/business/2018/10/15/savings-certificate-sales-pushing-up-govt-debtburden 
12. Hossain. S (2019) Savings tools sales cross FY target in 7 months as Jan amount hits record, 10 March, Retrieve from: http://www.newagebd.net/article/66929/savings-tools-sales-cross-fy-target-in7-months-as-jan-amount-hits-record

13. Imran, K. M., Jian-Zhou, T., Khan, M.K., Nauman, M. \& Jadoon, A.U., 2017. Determinants of National Saving: Evidence from South Asian Countries. European Academic Research, Vol. V, Issue 8/ November 2017.

14. Ministry of finance 2019, 'Socioeconomic Progress and Recent Macroeconomic Developments in Bangladesh' viewed 5thJanuary2021, https://mof.portal.gov.bd/sites/default/files/files/mof. Portal.gov.bd/

15. Mowla. G (2019) Govt. mulls making TIN, NID mandatory for savings certificates, 17 January, Retrieve from: https://www.dhakatribune.com/business/2019/01/17/govt-mulls-making-tin-nidmandatory-for-savings-certificates

16. Ministry of Finance, 2019, 'Socioeconomic Progress and Recent Macroeconomic Developments in Bangladesh' Ministry of Finance, Finance Division.

17. National Board of Revenue ( NBR) 2021, Income Tax Paripatra - 2021/2-22, viewed 5th January2021<https://nbr.gov.bd/uploads/paripatra/2021_Paripatra_dra<ft_final.pdf $>$.

18. National Budget Speech , 2021, 'Bangladesh Towards a Resilient Future Protecting Lives And Livelihoods' National Budget Speech 2021-2022 , Ministry of Finance Government of the People's Republic of Bangladesh.

19. NEWAGE, 2021 'Govt. lowers upper limits on purchase of NSCs ' The NEWAGE, Retrieve from: https://www.newagebd.net/article/123320/govt-lowers-upper-limits-on-purchase-of-nscs

20. World Bank, 2021 'Bangladesh Development- Update Moving Forward: Connectivity and Logistics to Strengthen Competitiveness' The World Bank Office, Dhaka, Bangladesh 